\author{
ANNA GuLCZYŃSKA \\ Uniwersytet im. Adama Mickiewicza \\ $w$ Poznaniu
}

\title{
HORTICULTURAL THERAPY AND GARDENING - COMPARISON OF DIMENSIONS
}

\begin{abstract}
AвSTRACt. Gulczyńska Anna, Horticultural Therapy and Gardening - Comparison of Dimensions [Hortiterapia czy praca w ogrodzie - podobieństwa i różnice]. Studia Edukacyjne nr 46, 2017, Poznań 2017, pp. 347-356. Adam Mickiewicz University Press. ISSN 1233-6688. DOI: 10.14746/sE.2017.46.22
\end{abstract}

There is growing attention to find and popularize untypical forms of therapy which should help patients in hospitals, occupational facilities and clinics. The main aim of the article is to show the differences between horticultural therapy as a form of therapy and work in a garden, which can also provide therapeutic results. Comparison of different determinants was a method to outline that proper understanding of the differences may be beneficial both for theoreticians and practitioners who use nature in order to improve their patients' health. However, it is useful for future teachers and could play a role in the teacher education process. As a conclusion, it has been established that source literature scientific reports focus rather on potential recipients or benefits which come from this form of therapy, whereas basic differences between gardening and horticultural therapy have been rarely mentioned. Analysis has helped to observe that there are many factors which differentiate therapeutic work in the garden from work in the garden which can bring therapeutic effects. Performing such an analysis seems to be significant in connection with the growing popularity of centers which offer this kind of therapy, and with the emergent dilemmas concerning how it differs from gardening and whether the therapy is worth the money invested in it.

Key words: horticultural therapy, gardening

\section{Introduction}

More and more institutions introduce horticultural therapy as a supportive form of therapy. The examples are hospitals, hippotherapy centers, daily care centers, occupational therapy workshops and special schools.

Horticultural therapy - in its core and function is often misunderstood, depreciated or even diminished to gardening. Therefore, it seemed crucial to 
answer the question what makes horticultural therapy a form of therapy and how it differs from a regular work in a garden. When can gardening become a horticultural therapy?

\section{Horticultural therapy - brief of history and definition}

Plants play a very important role in the life of every person. They have been present in human history since the beginning of its development.

Egyptian physicians were first to observe the therapeutical impact of plants and recommended walks in gardens to members of the royal family who had some mental disabilities.

Hildegarda of Bingen, the Middle Ages saint, believed that human beings should gain vital energy form four elements: water, fire, air, earth. She ordered to keep life-work balance and spend as much time as it is possible being in contact with nature.

An interest in the healing properties of gardens it developed mainly in the 17 th and 18 th centuries. Hospitals and sanatoriums were located in parks due to therapeutic role of nature.

One of the first scientists who proved that therapy in the garden is able to bring positive consequences was an American doctor, writer and pedagogue Benjamin Rush (XVIII / XIX century). At the end of nineteenth century the horticultural therapy was more and more used to treat mentally ill children. A famous British garden designer Gertrude Jekyll (XIX / XX century) wrote that a garden is a miraculous teacher of patience, diligence, thrift and most of all limitless generosity. The effectiveness of horticultural therapy was also confirmed, in the first half of the XX century, on the First and Second World War veterans who suffered from stress disorder and post-camp asthenia. ${ }^{1}$

Definitions of horticultural therapy proposed by different authors are alike. All of them emphasize using and benefiting from plants in order to improve human's health, some of them limit horticultural therapy to work with people with mental or physical disorders.

Horticultural therapy (garden therapy, Latin 'hortus' - garden) 'is one of the most recent forms of unconventional therapy using plants to improve physical and mental condition of a person'. ${ }^{2}$

${ }^{1}$ G. Zawiślak, Hortiterapia jako narzędzie wptywające na poprawę zdrowia psychicznego i fizycznego człowieka, Sectio Eee Horticultura, 2015, XXV (1), p. 22-24. For more historical information see: M.C. Cooper, Healing Gardens in Hospitals, Interdisciplinary Design and Research e-Journal, 2007, January, 1, 1, p. 1 and: M. Cylkowska-Nowak, S. Tobis, Zastosowanie hortikuloterapii w gerontologii, "Gerontologia Polska” 2014; 4, p. 97-158.

${ }^{2}$ G. Zawiślak, Hortiterapia jako narzędzie, p. 21. 
Another definition claims that 'horticultural therapy uses gardens and plants as therapeutic tools which constitute complement to rehabilitation of its alternative form ${ }^{\prime}{ }^{3}$

Christie et al., ${ }^{4}$ highlight a different aspect of horticultural therapy in practice which also appears to be important:

is typically conceptualized as an active and client-centred process, facilitated by trained therapists to achieve specific and documented treatment goals. It embeds the promotion of health and wellbeing, including physical and psychosocial functioning, as a core intended outcome in the context of an established treatment plan, such that the process itself acts as the therapeutic activity, rather than the end product.

For the purpose of this article the definition of Relf and Dorn ${ }^{5}$ seems to serve best:

Horticultural therapy may be defined as a process of using plants and garden-related activities to promote well-being of the mind, body and spirit, and is used by occupational therapists, physiotherapists, teachers, nurses, allied health workers, and activity workers. Just as talking through a pressing problem with a friend cannot be classified as either counselling or psychotherapy, simply working in the garden or cultivating plants should not be referred to as horticultural therapy. While both activities can certainly be considered to have a level of therapeutic value, in their basic form they lack a number of features such as client evaluation, goal setting and programmed interventions, which therefore prevents them from being classified as a therapy.

It seems most useful since in this paper, horticultural therapy is comprehended as therapeutic method using plants and actions related to improvement and maintaining health condition of a human in the physical, mental, cognitive and social aspects. Therefore the aim of horticultural therapy is not to succeed in gardening or nature, but to improve or maintain human's health. A person, who leads the therapy must possess appropriate qualifications.

In the definition above, the word 'method' was also used as a systematic way of acting which is a deliberate, pre-programmed process, submitted for verification and evaluation.

The basic tools used in horticultural therapy are plants taken from the natural environment, both gardens and wild nature. Additionally therapists can reach for different tools from garden magazines and folders, through magnifying glass, binoculars, microscopes, to outdoor workshops and online conferences with well-known experts.

${ }^{3}$ J. Majkowska-Gadomska, E. Mikulewicz, A. Dobrowolski, Hortiterapia - nowoczesna forma leczenia, [w:] Hortiterpaia - terapia wspomagajaca rehabilitacje dzieci i dorostych, red. B. Płoszaj-Witkowska, Olsztyn 2016, p. 75.

4 M.A. Christie et al., Personality Disorder and Intellectual Disability: The Impacts of Horticultural Therapy Within a Medium-Secure Unit, Journal of Therapeutic Horticulture, 2016, 26(1), p. 6.

${ }^{5}$ L.M. Baker, Essay: Nature's Pervading Influence: A therapy of growth, International Journal of Disability Development and Education, 2009, 56(1), p. 94. 


\section{Horticultural therapy - scope and use}

The results of scientific research concerning effectiveness of using horticultural therapy in various social groups are extensive. The research carried out by Brown et al. ${ }^{6}$ proved that employing horticultural therapy could positively influence the skills in five areas: cognitional, social, emotional, physical and physiological.

Cognitional benefits: improving concentration, enlarging vocabulary scope, broadening knowledge, gaining new skills, planning and observing, memory stimulation.

Social benefits: communication skills development, interactions among and beyond the group Emotional benefits: increasing self-esteem, trust and self-assessment boost, improving attentional capacity and engagement level, recognizing and improving creativity, reducing aggression and stress level.

Physical benefits: improving physical condition, developing gross and fine motor skills, increasing everyday life skills, improving eye coordination.

Physiological benefits: lower blood pressure and heart rate, decreased cortisol, reduced level of stress.

The comprehensive study of Zawiślak ${ }^{7}$, indicates that horticultural therapy is successfully used when working with people with mental and physical disorders, psychological disorders, Alzheimer's disease, autism and dementia. It is also recommended to people who are exposed to stress, addicted to alcohol and drugs, socially excluded, showing signs of professional burnout, victims of violence and crimes, with learning difficulties, overweight and paralysed.

Articles published in Journal of Therapeutic Horticulture also describe the studies which indicate advantages of horticultural therapy in work with patients with depression symptoms ${ }^{8}$, behavioral disorders ${ }^{9}$, adults with disabilities ${ }^{10}$, autism ${ }^{11}$, war veterans ${ }^{12}$, seniors ${ }^{13}$ or groups of parents and children.

6 S.P. Brown et al., Horticultural Therapy University of Florida: www.edis.ifas.ufl.edu/ ep145[access: 09.07.2017].

${ }_{7}$ G. Zawiślak, Hortiterapia jako narzędzie, p. 26.

8 J.F. Wilson, K.M. Christensen, The Relationship between Gardening and Depression among Individuals with Disabilities, Journal of Therapeutic Horticulture, 2011, 21(2), p. 28-41.

9 J. Trauth, Lighthouse Community School: A Case Study of a School for Behaviorally Challenged Youth, Journal of Therapeutic Horticulture, 2017, 27(1), p. 61-65.

${ }_{10}$ C.K.Y. Lai et al., An Exploratory Study on the Effect of Horticultural Therapy for Adults with Intellectual Disabilities, Journal of Therapeutic Horticulture, 2017, 27(1), p. 3-15.

11 K.M. Flick, The Application of a Horticultural Therapy Program for Preschool Children with Autism Spectrum Disorder, Journal of Therapeutic Horticulture, 2012, 22(1), p. 38-45.

${ }_{12}$ L.L. Fleming, Veteran to Farmer Programs: An Emerging Nature-Based Programming Trend, Journal of Therapeutic Horticulture, 2015, 25(1), p. 27-48; H.Z. Lorber, The Use of Horticulture in the Treatment of Post-Traumatic Stress Disorder in a Private Practice Setting, Journal of Therapeutic Horticulture, 2011, 21(1), p. 18-29.

${ }^{13}$ K. Haruyuki, K. Mitsunobu, The Effect of Horticultural Activity on the Cognitive Performance of Healthy Elderly Individuals, Journal of Therapeutic Horticulture, 2013, 23(2), p. 5-17. 
Despite the reference to specific therapeutic programs led by a relevant facility, there is a lack of emphasis on differences between therapeutic and ordinary work in a garden and why they are not equivalent conceptions or activities. ${ }^{14}$

American Horticultural Therapy Association ${ }^{15}$ drew attention to the fact, that conceptions related with therapy and/or work in a garden are often confused or inadequately understood. Horticultural therapy, therapeutic horticulture, social horticulture and vocational horticulture were distinguished. The first one has therapeutic character as it fits certain requirements (described in the table below), the second and third are activities using therapeutic function of a garden, though not being a method in a sense of deliberate employment of conscious and pre-programmed influence of horticultural therapy. The fourth one has occupational activity function, sometimes moneymaking, which can bring therapeutic effects, especially when concerning the context in which it is performed (prisons, rehabilitation centers).

1. Horticultural Therapy - is the engagement of a patient in horticultural activities with an assistance of a trained therapist in order to achieve specific and planned treatment/therapeutic goals. The most meaningful is the presence and engagement of the client/patient in the process of participation in horticultural activities itself, more than the final product. Recipients are the people with mental diseases and disorders, with disabilities - both mental and physical, and everyone who in some way is socially excluded.

2. Therapeutic Horticulture - is a process in which participants aim to improve their well-being through active or passive involvement in plants-related activities. In therapeutic horticulture program (if there is one), goals are not formed so actions do not need to be clinically defined or documented. Thus, it is hard to verify the way in which contact with nature brings the therapeutic effects.

3. Social horticulture is referred to leisure or recreational activity related to plants and gardening. A typical garden community or garden clubs are examples of a social setting. No treatment goals are defined, a therapist is not present and the focus is in on social interactions with gardening. Nature becomes rather a relevant background and context rather than a main tool of the process.

4. Vocational horticulture as a program is often a major component of horticultural therapy in context of work in horticulture industry professionally,

${ }^{14}$ G.G. Fried, M.J. Wichrowski, Horticultural therapy: A psychosocial treatment option at the Stephen D. Hassenfeld Children's Center for Cancer and Blood Disorders, Primary Psychiatry, 2008, 15(7), p. 73-77; J. Hilbers, A. Satharasinghe, Gardens and Therapeutic Horticulture in an Acute Healthcare Setting: Opportunities Provided by the Blooming Backyard Project at Prince of Wales Hospital, Sydney, Journal of Therapeutic Horticulture, 2013, 23(1), p. 35-47; I.M. Söderback, E. Schälander, Horticultural therapy: the 'healing garden and gardening in rehabilitation measures at Danderyd hospital rehabilitation clinic, Sweden Pediatric Rehabilitation, 2004, 7(4), p. 245-260.

${ }^{15}$ E.R.M. Diehl, Definitions and Positions, final_ht_position_paper_updated_409.pdf [Available: 11.07.2017]. 
either independently or semi-independently. Working individuals may have some type of disability, or stay beyond some social standards. Vocational horticultural programs are introduced in schools, residential or rehabilitation facilities, prisons or other places. ${ }^{16}$

\section{Horticultural therapy and gardening which may bring therapeutic effects - distinction factors}

Table 1 presents the contrast between horticultural therapy and gardening. Both activities may bring health improvement, better mood and a method to deal with emotions. However, there are basic differences between those two activities - horticulture therapy is a deliberate and intentional process whose goals are therapeutic and participation in activities is of crucial importance. Certainly, beautiful flowers, herbs and a neat garden are additional reasons for pride, satisfaction or growth of personal abilities, though they have a supporting role. In case of work in a garden the main goal is gardening and aesthetic effect itself. Mood improvement and general well-being are important, but not essential aim of work. Moneymaking purpose is not mentioned in the table below.

Table 1

Distinction factors between horticultural therapy and gardening

\begin{tabular}{|l|l|l|}
\hline \multicolumn{1}{|c|}{ Determinant } & \multicolumn{1}{|c|}{ Horticultural therapy } & \multicolumn{1}{c|}{ Gardening } \\
\hline $\begin{array}{l}\text { Recipient/patient/ } \\
\text { client }\end{array}$ & $\begin{array}{l}\text { 1. Person who needs professional } \\
\text { and dedicated therapy, he/she } \\
\text { has possibility and willingness } \\
\text { to participate in garden/nature- } \\
\text { related work. }\end{array}$ & $\begin{array}{l}\text { 1. Everyone who likes work in } \\
\text { a garden } \\
\text { 2. Everyone who must work } \\
\text { in a garden because of some } \\
\text { obligation to other people } \\
\text { (e.g. household member, } \\
\text { neighbours). }\end{array}$ \\
\hline $\begin{array}{l}\text { Assistant/person } \\
\text { conducting }\end{array}$ & $\begin{array}{l}\text { Qualified horticultural therapist } \\
\text { (pedagogues, psychologists, } \\
\text { gardeners, etc. who finished } \\
\text { qualified course or studies) }\end{array}$ & $\begin{array}{l}\text { No need of qualified assistant/ } \\
\text { coordinator (horticultural } \\
\text { therapist); work can be } \\
\text { undertaken by every person. } \\
\text { Assisting person may be } \\
\text { a qualified gardener, fruit } \\
\text { farmer - if there is a require of } \\
\text { a person who does gardening. }\end{array}$ \\
\hline
\end{tabular}

${ }^{16}$ The functions available in the source are supplemented by the author. See the source: American Horticultural Therapy Association. 


\begin{tabular}{|c|c|c|}
\hline Form & $\begin{array}{l}\text { 1. Often a group with the same } \\
\text { goal - therapeutic one. } \\
\text { 2. Active and passive. }\end{array}$ & $\begin{array}{l}\text { 1. More often individual. } \\
\text { 2. Active and passive. }\end{array}$ \\
\hline $\begin{array}{l}\text { Type of } \\
\text { knowledge } \\
\text { constituting } \\
\text { a base to activity }\end{array}$ & $\begin{array}{l}\text { Both: therapeutic about methods, } \\
\text { forms, therapeutic tools and } \\
\text { nature/gardening }\end{array}$ & $\begin{array}{l}\text { Nature (fruit, floristic, } \\
\text { gardening) }\end{array}$ \\
\hline Goals & $\begin{array}{l}\text { 1. Defined, formalized, written. } \\
\text { Often developed as a result of } \\
\text { work of team of pedagogues, } \\
\text { psychologists, occupational } \\
\text { therapists, psychiatrists, social } \\
\text { workers. } \\
\text { 2. Therapeutic - stated together in } \\
\text { view of client/patient's good. } \\
\text { 3. Group and individual. } \\
\text { 4. Personalized - dependent on } \\
\text { disease or disability. } \\
\text { 5. Stated with a place of } \\
\text { therapeutic activities. }\end{array}$ & $\begin{array}{l}\begin{array}{l}\text { Dependent on the type of } \\
\text { place and individual needs, } \\
\text { e.g. }\end{array} \\
\text { - Aesthetic - taking care of } \\
\text { plants or surroundings look, } \\
\text { - Hedonistic (for pleasure), } \\
\text { - Therapeutic - short } \\
\text { term, focused mostly on } \\
\text { dealing with tension or } \\
\text { undesired emotions } \\
\text { (e.g. coping with anxiety } \\
\text { or helplessness). }\end{array}$ \\
\hline $\begin{array}{l}\text { Change in } \\
\text { a participating } \\
\text { person }\end{array}$ & $\begin{array}{l}\text { Therapeutic, expected by reason } \\
\text { of contact with nature. }\end{array}$ & $\begin{array}{l}\text { Not expected concerning the } \\
\text { fact of contact with nature. }\end{array}$ \\
\hline $\begin{array}{l}\text { Method of } \\
\text { organization }\end{array}$ & $\begin{array}{l}\text { Determined by knowledge about: } \\
\text { - methodology and didactics } \\
\text { of educational process } \\
\text { organization, } \\
\text { - educational, psychological, } \\
\text { sociological factors (properly } \\
\text { qualified staff), } \\
\text { - participant/ participants of } \\
\text { activities in terms of: needs, } \\
\text { abilities, limitations, therapeutic } \\
\text { goals, } \\
\text { - conditions of particular } \\
\text { facility, including space for } \\
\text { horticultural therapy activities } \\
\text { (e.g. garden open or closed), }\end{array}$ & $\begin{array}{l}\text { Determined by knowledge } \\
\text { about sciences, especially } \\
\text { gardening, fruit, floristics etc. }\end{array}$ \\
\hline
\end{tabular}




\begin{tabular}{|c|c|c|}
\hline Scope of work & Determined by therapy goals & $\begin{array}{l}\text { Determined by needs coming } \\
\text { from the seasons, type of green } \\
\text { area and human's possibilities. }\end{array}$ \\
\hline $\begin{array}{l}\text { Level of } \\
\text { autonomy }\end{array}$ & $\begin{array}{l}\text { Low, indicated by therapy goals. } \\
\text { High - in case of continuing } \\
\text { activities independently. }\end{array}$ & $\begin{array}{l}\text { High, set individually. } \\
\text { Changes possible without } \\
\text { consultations. }\end{array}$ \\
\hline Place & $\begin{array}{l}\text { Specifically prepared and } \\
\text { planned (e.g. hospital facilities, } \\
\text { occupational therapy workshops). }\end{array}$ & $\begin{array}{l}\text { Each place in which the person } \\
\text { wants or must work (yard or } \\
\text { garden). }\end{array}$ \\
\hline Tools & $\begin{array}{l}\text { Determined both by methodology } \\
\text { of work in a garden and } \\
\text { therapeutic goals. }\end{array}$ & $\begin{array}{l}\text { Determined by distinctive } \\
\text { nature of gardening } \\
\text { and individual financial } \\
\text { possibilities. }\end{array}$ \\
\hline $\begin{array}{l}\text { Total time of } \\
\text { process }\end{array}$ & $\begin{array}{l}\text { 1. Set by formal requirements: } \\
\text { - Therapy goals } \\
\text { - Financial } \\
\text { - Localization - space which can } \\
\text { be arranged } \\
\text { - Human factor: qualified } \\
\text { specialists, possibilities and } \\
\text { willingness of clients/patients. } \\
\text { 2. Undertaken as therapy, not } \\
\text { only within leisure time frame. }\end{array}$ & $\begin{array}{l}\text { 1. Dependent on individual } \\
\text { abilities of person } \\
\text { undertaking garden-related } \\
\text { activities. } \\
\text { 2. Ending with passing the } \\
\text { obligation (formal or } \\
\text { informal). } \\
\text { 3. Most often undertaken } \\
\text { within leisure time frame. }\end{array}$ \\
\hline Evaluation & $\begin{array}{l}\text { 1. Required, defined, formalized. } \\
\text { 2. Done in view of therapeutic } \\
\text { goals. }\end{array}$ & $\begin{array}{l}\text { 1. Not required, voluntary. } \\
\text { 2. Often done in aesthetic } \\
\text { categories, informal (e.g. } \\
\text { like it or not). }\end{array}$ \\
\hline Supervision & $\begin{array}{l}\text { Required, regular, with qualified } \\
\text { horticultural therapist. }\end{array}$ & $\begin{array}{l}\text { Not required, voluntary, more } \\
\text { like consultation. }\end{array}$ \\
\hline
\end{tabular}

\section{Conclusions}

The aim of the article was to present differences between therapeutic work in a garden and gardening which may bring therapeutic results.

Horticultural therapy goals come from established work paradigm, theoretical conception or recipients of influencing. They are specific and determined. They must be formed extremely cautiously and in deliberate way as they 
are destined to wide range of patients with psychiatric diagnosis or movement disorders. Horticultural therapy may be used as a method in various areas of work. Its therapeutic performance is very wide, although it is important to remember the difference between horticultural therapy and gardening just as differences between punishing and upbringing or talk to a friend and to a therapist. These contrasts were introduced in the table. Essential differences mentioned above are often left aside - both in designing therapeutic influences and their evaluation. The factors presented in the table above emphasize the need of careful consideration when designing horticultural therapy influences. It may be also helpful in process of education of future horticultural therapists, as well as for the families of horticultural therapy recipients. Relatives of people with disorders, diseases or socially excluded often seek new forms of therapies; therefore it is advisable to have access to reliable sources knowledge or specialists, who are able to pass it clearly preferably reducing skepticism at the same time.

Disclosure of interest: the author reports no conflicts of interest. The author alone is responsible for the content and writing of the paper.

\section{BIBLIOGRAPHY}

Baker L.M., Essay: Nature's Pervading Influence: A therapy of growth, International Journal of Disability Development and Education, 2009, 56(1), p. 93-96; https://education. uq.edu.au/profile/296/lynne-baker [access: 07.07.2017].

Brown S.P., Worden E.C., Frohne T.M., Sullivan J., Horticultural Therapy University of Florida, www.edis.ifas.ufl.edu/ep145 [access: 09.07.2017].

Christie M.A., Thomson M., Millerand P.K., Cole F., Personality Disorder and Intellectual Disability: The Impacts of Horticultural Therapy Within a Medium-Secure Unit, Journal of Therapeutic Horticulture, 2016, 26(1), p. 3-17, http:/ / www.ahta.org/the-journal-of-therapeutic-horticulture [access: 03.07.2017].

Cooper M.C., Healing Gardens in Hospitals, Interdisciplinary Design and Research e-Journal, 2007, January, 1, 1.

Cylkowska-Nowak M., Tobis S., Zastosowanie hortikuloterapii w gerontologii, Gerontologia Polska, 2014, 4.

Diehl E.R.M., Definitions and Positions, final_ht_position_paper_updated_409.pdf [Available: 11.07.2017].

Fleming L.L., Veteran to Farmer Programs: An Emerging Nature-Based Programming Trend, Journal of Therapeutic Horticulture, 2015, 25(1), p.27-48, http://www.ahta.org/ the-journal-of-therapeutic-horticulture [access: 12.07.2017].

Flick K.M., The Application of a Horticultural Therapy Program for Preschool Children with Autism Spectrum Disorder, Journal of Therapeutic Horticulture 2012, 22(1), p. 38-45, http:/ / www.ahta.org/the-journal-of-therapeutic-horticulture [access: 12.07.2017].

Fried G.G., Wichrowski M.J., Horticultural therapy: A psychosocial treatment option at the Stephen D. Hassenfeld Children's Center for Cancer and Blood Disorders, Primary Psychiatry, 2008, 15(7). 
Haruyuki K., Mitsunobu K., The Effect of Horticultural Activity on the Cognitive Performance of Healthy Elderly Individuals, Journal of Therapeutic Horticulture, 2013, 23(2), p. 5-17, http:/ / www.ahta.org/the-journal-of-therapeutic-horticulture [access: 17.07.2017].

Hilbers J., Satharasinghe A., Gardens and Therapeutic Horticulture in an Acute Healthcare Setting: Opportunities Provided by the Blooming Backyard Project at Prince of Wales Hospital, Sydney, Journal of Therapeutic Horticulture, 2013, 23(1), p. 35-47, http:/ / www.ahta. org/the-journal-of-therapeutic-horticulture [access: 18.07.2017].

Lai C.K.Y., Ho L.Y., Kwan R.Y., Fung C.Y., Mak Y.W., An Exploratory Study on the Effect of Horticultural Therapy for Adults with Intellectual Disabilities, Journal of Therapeutic Horticulture, 2017, 27(1), p. 3-15, http://www.ahta.org/the-journal-of-therapeutic-horticulture [access: 22.04.2017].

Lorber H.Z., The Use of Horticulture in the Treatment of Post-Traumatic Stress Disorder in a Private Practice Setting, Journal of Therapeutic Horticulture, 2011, 21(1), p. 18-29, http:/ / www.ahta.org/the-journal-of-therapeutic-horticulture [access: 11.06.2017].

Majkowska-Gadomska J., Mikulewicz E., Dobrowolski A., Hortiterapia - nowoczesna forma leczenia, [w:] Hortiterpaia - terapia wspomagajaca rehabilitację dzieci i dorostych, red. B. Płoszaj-Witkowska, Wydawnictwo Uniwersytetu Warmińsko-Mazurskiego, Olsztyn 2016.

Söderback I.M., Schälander E., Horticultural therapy: the 'healing garden' and gardening in rehabilitation measures at Danderyd hospital rehabilitation clinic, Sweden Pediatric Rehabilitation, 2004, 7(4).

Trauth J., Lighthouse Community School: A Case Study of a School for Behaviorally Challenged Youth, Journal of Therapeutic Horticulture, 2017, 27(1).

Wilson J.F., Christensen K.M., The Relationship between Gardening and Depression among Individuals with Disabilities, Journal of Therapeutic Horticulture, 2011, 21(2).

Zawiślak G., Hortiterapia jako narzędzie wptywające na poprawę zdrowia psychicznego i fizycznego człowieka, Sectio Eee Horticultura, 2015, XXV (1). 